\title{
THE ABC TECHNIQUE OF FINANCING REAL ESTATE ACQUISITIONS: THE TAX MOTIVATED LEASEHOLD
}

\section{Mrles H. Tanenbadm $\dagger$}

Deferral of income tax liability is a prime objective of tax planning. To this end, practitioners strive to defer income recognition, ${ }^{1}$ accelerate deductions, ${ }^{2}$ and delay filing and payment. ${ }^{3}$ One of the most challenging battlefields in the deferral struggle involves the treatment of expenditures for capital assets having useful lives extending beyond the year of purchase. A rudimentary principle of tax law is that the purchase price of such assets is not deductible when paid or incurred $;^{4}$ in order to recoup his investment, the taxpayer must rely on the depreciation deduction prorated over the useful life of the asset. ${ }^{5}$

Undaunted by the seeming finality of this rule, enterprising practitioners have carved out a significant exception by employing what has come to be known as the ABC transaction. ${ }^{6}$ This device, which will be described later in greater detail, creates for the party financing the purchase of an asset an ownership interest in it. If this is successfully accomplished, the owner of the larger underlying equity interest-the one for whose benefit the financing was arranged-will not be taxed on income used to repay the financier, and the financed portion of the purchase price will not become part of his basis for depreciation. The net result is the same as if the real purchaser were permitted a deduction for the financed portion of the purchase price in the year in which the loan is repaid, rather than having to recover his investment gradually by depreciation deductions over the useful life of the property.

This Article will be concerned with the legal problems raised by the attempted application of the $A B C$ technique to the acquisition of

† B.S. 1952, LL.B. 1957, University of Pennsylvania. Member, Pennsylvania Bar.

1 See, e.g., INT. REv. CoDE of 1954, § 453(a) (installment method of reporting gain in long term payout transactions); INT. REV. CODE OF 1954, §§ 301-95 (nonrecognition).

2 See, e.g., INT. REv. CODE of 1954, $\$ 167$ (b) (2) (accelerated depreciation); INT. REv. CODE OF 1954, \$266 (deducting rather than capitalizing interest and taxes); INT. REv. CODE OF 1954, $\$ 174$ (charging off rather than amortizing research and development expenses).

3 See, e.g., INT. REv. CODE of 1954, $\$ 6081$ (extending time for filing returns); INT. REv. CoDE of 1954, $\$ \S 6161-66$ (extending time for payment of taxes).

4 INT. Rev. Code of 1954, §263.

5 INT. Rev. Code of $1954, \S 167$.

6 For a brief explanation of the ABC transaction, see Welsch, Acquiring Properties Through Oil Payments and Related Methods, 32 TAXEs 494 (1954). 
real estate. The typical $A B C$ pattern varies the normal form of real estate financing. The party financing the purchase becomes the owner of a leasehold, and the payments to him are designated as rent. The central question is whether these characterizations will be controlling for tax purposes.

The attempt to mold vendor-purchaser transactions into other commonly recognized forms to achieve specific tax consequences creates thorny tax problems, not the least of which is a semantic one. Words which persons not intimately involved with tax law employ with ease-sale, lease, debt, property, income-become troublesome in assessing the tax results of an $\mathrm{ABC}$ real estate acquisition. The government and the courts, if not sidetracked by word games, can be expected to scrutinize the form of the transaction, particularly the altered interest of the financing party, to determine whether form is confirmed by substance.

Throughout this Article, the seller of the property will be referred to as $A$, the buyer as $B$, and the financing party as $C$, and the transaction will be called $A B C$.

\section{Acquisitions Financed by Purchase Money Mortgage}

To better understand the $A B C$ technique and its objective, it is first necessary to review the tax consequences of an ordinary acquisition of rental property by purchase money mortgage.

It will be assumed that the premises will be occupied under a net lease arrangement whereby the tenant bears directly all of the costs of maintenance, repairs, and taxes, while paying a net fixed rental to the purchaser, or perhaps in part to the mortgagee $C$, for B's account. In a substantial number of instances the credit position of the tenant and the value of the real estate is such that the amortization of the principal and interest of the mortgage can be arranged to consume the entire net rental receipts. ${ }^{7}$

Assuming that $\mathrm{A}$ is not a dealer in real estate, income to him on the sale will be taxable as capital gain. ${ }^{8} \mathrm{~B}$ will have ordinary rental income ${ }^{9}$ but will be entitled to deductions for interest paid to $C^{10}$ and for depreciation of any buildings on the property. ${ }^{11}$ Ordinarily, C's only income in the transaction will be the interest paid to him by B. ${ }^{12}$

${ }^{7}$ No reference is made to the credit standing of the purchaser since it is rare, in the circumstances described, that he will subject his other assets to repayment of the mortgage obligation.

8 INT. REv. CoDE of 1954, §1231(a). See text accompanying note 73 infra.

9 INT. Rev. CODE OF 1954, §61(a) (5).

10 INT. REv. CODE of 1954, \&163.

11 INT. Rev. CoDE of 1954, \$\$167 (a), (f), 1011-12.

12 See INT. REv. Code of 1954, §61(a) (4). 
If, however, he disposes of the mortgage for a price greater than his basis in it, he will have capital gain. ${ }^{13}$

If the mortgage is a conventional one, it will involve level payments apportioned between interest and principal. The bulk of C's interest income will be realized in the early years while the amortization of principal is low. If $B$ uses other than the straight line method, his depreciation deduction for the same years may be greater than the amortization of the mortgage principal; ${ }^{14}$ therefore, his interest and depreciation deductions combined may exceed his annual cash disbursement to C. Before long, however, the situation will be reversed. In any event, it is likely that the aggregate depreciation deduction at the time the mortgage obligation is satisfied will be less than the principal payments. ${ }^{15}$ This is not surprising since a mortgagee will rarely finance property over a period in excess of that portion of its useful life which the ratio of the financed portion bears to the total purchase price. ${ }^{16}$ When: by the end of the mortgage period, $B$ will have disbursed to $C$ principal payments exceeding his depreciation deduction, he will have more invested than the deductions allowed to him by that point.

\section{Acquisitions Financed by Sale of Leasehold and Remainder} INTERESTS

In an $A B C$ transaction, $A$ sells to $C$ a leasehold interest of relatively long-term duration-calculated to yield to $\mathrm{C}$ a return matching the going rate of interest on indebtedness-and the remainder interest after such leasehold to $B$. Whereas in the previous example $B$ was the owner of the entire fee and thus had the right to receive all of the income therefrom, in the altered form of acquisition, $B$ is technically not entitled to receive any of the rent. Indeed, the purpose of changing B's interest is to eliminate the element of rent from his gross income. Though $\mathrm{C}$ will thereafter receive rent instead of interest payments, the tax consequences to it are virtually unchanged ${ }^{17}$ regardless

13 See INT. Rev. Code of 1954, § 1221.

14 Treas. Reg. $\$ 1.167$ (b) -0(b) (1956) permits a taxpayer, not otherwise entitled to accelerated depreciation under INT. REV. CODE of 1954, $\$ 167$ (b), to use the declining balance method with the rate limited to $150 \%$ of that applicable to the straight line method.

15 Even using the straight line method, a mortgagor making level payments of principal and interest may have an aggregate depreciation deduction in early years that exceeds his amortization of principal.

16 If the financing were arranged on the security of the property alone, it is possible that $B$ could abandon the property prior to the time his annual payment of mortgage principal exceeded his depreciation deduction. B would, however, recognize gain at that time, with a basis less than the amount of the mortgage. See Crane v. Commissioner, 331 U.S. 1 (1947).

$17 \mathrm{C}$ would have a basis in the leasehold equal to its cost, which would be amortizable ratably over the term of the lease. Consequently, the difference between the 
of how the taxing authorities ultimately view the transaction. The principal inquiry is whether the characterization of C's interest as a leasehold is a mere formality or whether it involves so substantial a difference in the incidents of the interests held by $\mathrm{B}$ and $\mathrm{C}$ to warrant excluding the rent from B's gross income.

One possible distinction between the ordinary purchase money mortgage transaction and the $A B C$ acquisition is the lack of a personal obligation from $\mathrm{B}$ to $\mathrm{C}$ in the latter. However, while mortgages often do include such an obligation, it is not uncommon for the bond obligee to be a straw party; some mortgages do not even include a bond. In either of these events, C's remedy realistically is limited to the value of the property itself by enforcement of the mortgage lien, as is somewhat the case in the $A B C$ situation.

A second difference-the absence of a lien by $C$ against the entire fee-is more material. This limits C's claim-aside from his possessory rights in the leasehold-to the assets of the tenant in possession.

The facts surrounding the acquisition, however, in view of C's willingness to look solely to the leasehold for repayment, could be such that as a practical matter these distinctions would lose any significance they might otherwise have. C's tenant might have a triple-A credit rating so that its obligation under the lease would provide greater security than the value of the land and B's obligation under a mortgage. In that case, were it shown that B induced C to "purchase" the leasehold on the strength of the tenant's credit, a strong contention could be made that C's interest is a mere indebtedness cast in the form of a leasehold. And, if the return to $C$ was calculated to yield the going rate of interest on purchase money mortgages, the argument for taxing $B$ on the rent is strengthened. ${ }^{18}$

An alternate contention which might defeat the tax objectives of the $A B C$ transaction is that the "sale" of the leasehold to $C$ is actually an assignment of future rent by $B$. The result would be to hold $B$

amount paid and received would represent the interest on a conventional mortgage. The only possible change in C's tax position would be a favorable one. Whereas with a mortgage it would receive the greater part of its interest income in early years, the straight line amortization of the leasehold investment would level C's income over the entire term, thus postponing taxation. Because of this factor, $\mathrm{C}$ might realize capital gain by selling the leasehold after several years of relatively light income during which amortization of its basis will have reduced it below the discounted value of the leasehold. See Walter H. Sutliff, 46 B.T.A. 446 (1942).

18 See 5 Mertens, Federal Income Taxation $\$ 30.03$ (1956). An indebtedness may be found although the source of repayment is restricted. See Clay Drilling Co., 6 T.C. 324 (1946), acq., 1946-2 Cum. BuLL. 1; Western Woodwork \& Lumber Co., 16 P-H Tax Ct. Mem. 430 (1947) ; I.T. 2931, XIV-2 CUM. Bull. 56 (1935); I.T. 3283, 1939-1 Cum. BuLL. 81. A mortgage, though not supported by the personai obligation of the mortgagor, is considered an indebtedness for tax purposes. 
taxable for the amount paid by $C$ to $A$ for the acquisition of the property by $B$, or possibly for the rent as it will be paid to $C$ during the term of the leasehold, as in the mortgage situation.

Thus the success of the $A B C$ technique depends on the resolution of two problems of characterization: does $C$ hold an indebtedness or a leasehold interest in the property; and is C's interest the classical "tree," producing taxable income for C, or the "fruit" whose income is taxable to its constructive assignor, $\mathrm{B}$.

\section{A. Leasehold or Indebtedness}

Although there are no tax cases dealing expressly with the ABC technique in real estate transactions, there are decisions in the analogous areas of oil payments, ground rents, life estates, and easements which bear on the questions raised. The only relevant decision involving an ordinary real estate transaction is Helvering v. F. \& R. Lazarus $\mathcal{E} C o .{ }^{19}$ which held that a conveyance of a fee simple title would be treated as a mortgage for tax purposes when such treatment accorded with the true intent of the parties. ${ }^{20}$ The broad principle established by that case covers any transaction in which the form differs from the substance in terms of the economic incidents of ownership. However, in the $A B C$ transaction, the form and the substance, in terms of economic risk, are the same. The only question is whether the tax treatment should recognize that in practical effect the transaction has the same function as a loan.

\section{Oil Payments-The Classic ABC Transaction}

In view of the percentage depletion provisions of the Internal Revenue Code, ${ }^{21}$ which provide for a tax deduction without reference to basis and anticipated return, it is even more desirable in the oil industry than in real estate to have the benefit of a current deduction for as much of the cost of acquisition as is possible. Hence, ABC transactions-which originated in oil dealings-are extremely important to oil producers.

The technique commonly employed by $B$ to finance the acquisition of A's oil producing properties involves the creation of an oil paymentan interest created by contract whereby the holder becomes the "owner" of a fractional share of the proceeds of production, limited to a specific

19308 U.S. 252 (1939).

20 Accord, Commissioner v. H. F. Neighbors Realty, 81 F.2d 173 (6th Cir. 1936) ; Akron Dry Goods, 18 T.C. 1143 (1952), aff'd per curiam, 218 F.2d 290 (6th Cir. 1954); Rev. Rul. 54-9, 1954-1 Cum. BuLl. 20.

21 INT. Rev. Code of 1954, §613. 
amount, payable in dollars or barrels of oil from a stated oil reserve, if, as, and when the oil is extracted. ${ }^{22}$ The transaction usually takes the following form. A sells all of his rights in the producing properties to $B$ except for an oil payment which he reserves from the grant for himself. Thereafter, and as part of the same transaction, A sells the reserved oil payment to C, whose function is to finance B's acquisition. Since geological tests forecast minimum oil reserves fairly accurately, the sole risks are the market for oil-affecting the quantity produced and price received-and the production quotas imposed by state law. To protect $\mathrm{C}$ from irregular payments due to these contingencies, it is common to provide that he will receive interest in case of delay. ${ }^{23}$

As in the $A B C$ real estate situation, there is no obligation from $B$ to $\mathrm{C}$; $\mathrm{C}$ must assume the risks of production and marketing. But these risks are so minimal that $\mathrm{C}$, normally a financial institution, receives a return equivalent to normal interest rates.

In Thomas v. Perkins, ${ }^{24}$ the Supreme Court held that the assignees of a working interest, subject to a reserved oil payment held by the

22 See Kuntz, Assignments of Oil Payments, 31 TAxes 863, 864 (1953); Welsch, Tax Aspects of Giving and Disposing of Interests in Oil and Gas, 31 TAXEs 855, 857 (1953). An example of a substantial ABC transaction was included in a proxy statement issued to the shareholders of Allied Chemical Corp. on January 12, 1962 with respect to a proposed merger. The information disclosed concerned the acquisition by the other party to the merger of a $5 \%$ interest in oil and gas producing properties:

The producing properties acquired were subject to a reserved production payment in the principal amount of $\$ 58,333,333$ (applicable to Union's $\%$ ths interest), which, together with basic interest at $55 \% \%$ and $6 \% / 8 \%$, commitment fees and certain closing costs, is being discharged out of approximately $80 \%$ of the gross revenue, less production taxes, from the sale of oil and gas produced from the properties. Commencing upon liquidation of the principal and basic interest (estimated to be 1970 ), $40 \%$ of the gross revenue, less production taxes, from the sale of such oil and gas will continue to be dedicated to the discharge of deferred interest computed at $3 \%$ per annum on the unpaid portion of the final $\%$ ths balance of the production payment. It is estimated that the deferred interest (estimated to be $\$ 4,800,000$ ) will be retired through available production from such properties by 1972 . . . .

The reserved production payment is regarded as an economic interest in the oil and gas in place and is not included in the accompanying balance sheet as cost of property and liabilities. During the period of payout Union receives and records in its accounts the net proceeds from sales of oil or gas which remain after application of the appropriate percentage of such sales to the satisfaction of the production payment. Between November 1 , and December 31,1960 , production applicable to the percentage of interest held by the production payment holder (Union's \%ths interest only) amounted to $\$ 1,524,000$, and for the ten months ended October 31, 1961, such production amounted to $\$ 7,036,000$.

During the payout period of the production payment, Union pays all of the operating costs attributable to the working interest acquired. The costs of producing the oil and gas reserved for the production payment have been capitalized in the accounts as additional costs of the properties so acquired and are being amortized over the estimated lives of such properties on a unit-of-production basis.

23 See note 22 supra.

24301 U.S. 655 (1937). 
assignors, did not have to include in their income the payments made to the holders of the oil payment. The Court first reasoned that a transferor of a working interest in oil, who reserves an oil payment, is required to recognize gain only to the extent of the interest actually conveyed. ${ }^{25}$ Referring to state law which regarded the holder of an oil payment as the owner of an interest in oil in place, it then stated that the oil needed to satisfy the oil payment was still an investment of the transferor for which he was entitled to a depletion deduction. ${ }^{28}$ Inasmuch as the depletion deduction involves an apportionment of gross income from the oil property, the gross income with respect to the oil payment belongs to its holder. Therefore, the holder of the working interest did not, for tax purposes, have to account for the income paid to the owner of the oil payment. ${ }^{27}$

The result in Thomas $v$. Perkins was a boon to purchasers of working interests. It allowed them to exclude the costs of oil payment financing from their gross income and from their basis for depletion. After this case, the Internal Revenue Service made a practice of issuing rulings in oil payment situations to the effect that: A realizes capital gain on the sale of its working interest, provided it is not a dealer in such property ; $\mathrm{B}$ is not required to include in his gross income any disbursement to $C$ for oil payments, and of course is not entitled to claim depletion with respect to such payments; and $C$ is entitled to amortize its basis in the oil payment as a deduction from gross receipts. During the summer of 1961, the Service temporarily discontinued these rulings to reconsider its position, ${ }^{28}$ and announced that it would shortly publish a statement of its policy toward $A B C$ transactions. ${ }^{29}$ The promised comprehensive ruling, however, has not yet appeared.

\section{Ground Rents}

A perpetual leasehold interest known as a ground rent is recognized under the laws of Maryland. Prior to 1884, such ground rents were not redeemable unless the lease expressly so provided; they have since been made redeemable after a minimum period upon payment to the owner of an amount equal to the capitalized rental at six percent.

25 The Court relied on Palmer v. Bender, 287 U.S. 551 (1933). See also Burnet v. Harmel, 287 U.S. 103 (1932).

26 See Palmer v. Bender, supra note 25, at 557-58.

27 Thomas v. Perkins, 301 U.S. 655 (1937). The dissent objected that the question of whether $C$ owned an oil payment was irrelevant to the issue of whether $B$, the owner of the base interest, was to be taxed on all the income. Id. at 663 . Cf. O. W. Killam, 33 T.C. 345 (1959); Jay H. Floyd, 30 P-H Tax Ct. Mem. 325 (1961).

28 Technical Information Release No. 326, July 17, 1961. Apparently the Service wished to study the applicability of Commissioner v. P. G. Lake, Inc., 356 U.S. 260 (1958), notes 58, 60 infra and accompanying text. See Technical Information Release No. 333, August 10, 1961.

29 Technical Information Release No. 338, Sept. 15, 1961. 
The tax aspects of this interest in property were considered in Commissioner $v$. Simmers' Estate. ${ }^{30}$ The owner of property divided it into lots and built houses on each plot. The ground was leased to a straw corporation for a ninety-nine year term, perpetually renewable. The owner then sold the houses, the purchasers receiving an assignment of the ground lease from the corporation, which could be redeemed in five years. The result, as stated by the court, was that "in common parlance the purchaser owns the house and the builder the land. The interest of the latter is held to be realty and the interest of the former personalty under the Maryland decisions." 31

The Commissioner contended that the ground rent, being redeemable after five years, was in practical effect a mortgage, the builder retaining only "the bare legal title." $\mathrm{He}$ argued that as a consequence the builder was in receipt of income measured by the purchase price of the house and the fair market value of the retained ground rent. The Court of Appeals for the Fourth Circuit, with one judge dissenting, disagreed, stating:

While the economic relation between lessor and lessee resembles that of mortgagor and mortgagee, there is the important difference that the purchaser can never be compelled to pay the so-called mortgage debt. Ordinarily, a vendormortgagee receives something of value in exchange for the transfer of the land, that is, the obligation of the vendeemortgagor, which in Maryland is usually in the form of a note, to pay a definite sum at a fixed time in the future. But the vendor in the ground rent system holds no such obligation and can recover the principal sum only by the voluntary redemption of the rent by the vendee or a sale of the rent to a third party. The difference is vital because there is no realization of taxable gain until one or the other of these events occurs. ${ }^{32}$

The court was obviously referring to the absence of any obligation by the "debtor" to make payment of the "principal"-the ground rent - since there was no fixed maturity date at which payment would be due. Perhaps the key to the court's decision was its use of the word "ordinarily" since there have been cases in which the absence of a fixed maturity date did not preclude considering an interest held by the taxpayer as an indebtedness. ${ }^{33}$ Essentially, the decision of the court was that in view of the absence of a fixed maturity date, the

30231 F.2d 909 (4th Cir. 1956).

31 Id. at 911.

32 Id. at 915 . (Emphasis added.)

33 See note 18 supra. 
form of the transaction would govern, since all the "ordinary" economic incidents of what the Commissioner argued was the substance of the transaction were not present.

After failing in a later case ${ }^{34}$ to persuade the court to overrule Simmers Estate, the Service announced that it would regard Maryland ground rents as leasehold interests, ${ }^{35}$ but would deny the lessees the interest deduction for their rent payments which they had previously enjoyed. ${ }^{30}$

Ground rents are also used in Pennsylvania as a means of providing security for deferred payments on the sale of real estate. In one case, the Court of Appeals for the Third Circuit regarded a redeemable ground rent as an indebtedness for tax purposes, notwithstanding ample authority in Pennsylvania case law that a ground rent is a separate estate in real property. ${ }^{37}$ The taxpayer sold real estate, receiving a cash consideration of $\$ 500,000$ and a ground rent of $\$ 800,000$ payable in ten years, in addition to an annual ground rent of $\$ 40,000$. The buyer had the option to pay the $\$ 800,000$ ground rent at any time during the ten-year period and in fact did so over the first three years. The court held that the entire consideration was taxable in the year of sale despite the form of the transaction. The appellate court stressed the economic realities of the sale: the property was in the heart of an urban business center; half a million dollars was paid in cash; the fair market value of the property was amply sufficient to secure the ground rent; $\$ 200,000$ was paid in the first year; and the ground rent was a "gilt-edged security of the highest type." The court also quoted the rationale of the Tax Board:

We have no disposition to deny these [Pennsylvania] authorities, but do not regard them as changing the method of Federal income taxation on realty sales made in Pennsylvania from what they ordinarily are in other states. ${ }^{38}$

Although the Fourth Circuit in Simmers' Estate did not comment on this decision, it is obvious that the ten-year ground rent, which by its terms provided a maturity date for payment, was distinguishable from the Maryland ground rent. The significance of the Third Circuit decision is twofold. First, the court disregarded form when it found no significant difference between the substance of the ground rent and a mortgage. Secondly, the court's emphasis on the need for

34 Welsh Homes, Inc. v. Commissioner, 279 F.2d 391 (4th Cir. 1960).

35 Technical Information Release No. 328, July 21, 1961.

38 Int. Rev. Serv. Release, July 21, 1961.

37 Pennsylvania $C_{0}$. for Ins. on Lives and Granting Annuities v. Commissioner, 52 F.2d 601 (3d Cir. 1931).

38 Id. at 601-02. 
uniform tax results indicated a tendency to disregard characterizations based upon established state law. Nevertheless, the factual variances from the Maryland case support the difference in result and illustrate the line-drawing problem presented. ${ }^{39}$

The Maryland ground rent is not adaptable to the $A B C$ technique, for the redemption payment would constitute an investment by $B$ without a corresponding deduction. However, the decision in Simmers' Estate that the form of the leasehold transaction controlled the tax result where the economic attributes of a lease were present should provide precedent for the contention that C's leasehold interest in the $A B C$ transaction should likewise be recognized in accordance with its form.

\section{Life Estates}

A life estate has long been recognized in common law as a separate interest in real property, distinct from the remainder. This distinction has also been recognized in tax law..$^{40}$ The consideration received upon the sale of a life estate by the owner of a fee who retains the reversion is taxed as capital gain, ${ }^{41}$ and any rental income received by the owner of the life interest is taxable to him and not to the holder of the reversion. ${ }^{42}$ It has also been held that a remainderman who purchases a life estate may amortize the cost of acquiring the life interest over the expected life of the original tenant. ${ }^{43}$ The principles of taxation of life estates are well established. ${ }^{44}$

Uncertainty of life expectancy limits the usefulness of the life estate as a financing device to special situations. If $\mathrm{C}$ acquires a life estate and $B$ the remainder interest, it is clear that the payment of rent to $\mathrm{C}$ will not be taxable to $\mathrm{B} .{ }^{45} \mathrm{C}$ can protect its investment against the possibility of a short life by purchasing a policy of life insurance which will provide decreasing coverage over the years. B can protect himself against the opposite contingency-that C's interest will continue beyond the time on the basis of which the purchase price

39 See Treas. Reg. $\$ 1.163-1$ (b) (1962), which determines the deductibility of ground rents as interest on the basis of whether they are redeemable on a fixed date.

40 See Estate of Camden, 47 B.T.A. 926 (1942), aff'd per curiam, 139 F.2d 697 (6th Cir. 1944), nonacq., 1943 CuM. Bulx. 28.

41 Ibid. See Allen v. First Nat'l Bank \& Trust Co., 157 F.2d 592 (5th Cir. 1946), cert. denied, 330 U.S. 828 (1947); McAllister v. Commissioner, 157 F.2d 235 (2d Cir. 1946), cert. denied, 330 U.S. 826 (1947) ; Bell's Estate v. Commissioner, 137 F.2d 454 (8th Cir. 1943), reversing 46 B.T.A. 484 (1942).

42 See note 40 supra; Blair v. Commissioner, 300 U.S. 5 (1937).

43 Bell v. Harrison, 212 F.2d 253 (7th Cir. 1954); William N. Fry, Jr., 31 T.C. 522 (1958), aff'd, 283 F.2d 869 (6th Cir. 1960), nonacq., 1960-2 Cum. Buls. 8.

44 See generally Note, 69 Harv. L. REv. 737 (1956); Note, Federal Taxation of Oil Payment Transactions, 104 U. PA. L. Rev. 1088 (1956).

45 See notes $40-41$ supra. 
was apportioned between them-by buying an annuity policy. But these added insurance costs and the possibility that the annuity will not be economically commensurate with B's loss if the measuring life is extremely long, limit the utility of the life estate device to family situations.

Nevertheless, it is significant to exponents of the $A B C$ technique that the holders of a life estate and a remainder interest in the same property are recognized, for tax purposes, as having distinct and independent property interests. Except for the fact that a leasehold is for a set term whereas a life estate is contingent on survival, the material attributes of the two are identical. Therefore, the tax treatment of life estates, when added to the oil payment and ground rent decisions, gives some additional support for the result sought in the $A B C$ real estate transaction.

\section{Easements}

The conveyance of a perpetual easement which leaves the servient tenement unfit for any use has been treated for tax purposes as a sale or exchange of the entire property..$^{46}$ If, however, the owner can still use the property, the consideration received is applied to reduce his basis and any excess is treated as capital gain on the theory that there has been a disposition of a severable interest in property-the classic "tree," and not merely its "fruit." 47 Significantly, the beneficiary of the easement acquires only a possessory right, yet is treated for tax purposes as if he held an estate in land, severed from the fee. It follows that the revenue from an income-producing easement is taxable to the owner of the easement rather than to the owner of the servient tenement. ${ }^{48}$

A perpetual easement obviously differs from a leasehold in many respects. The critical distinction from a tax standpoint is that the perpetual easement is an estate coextensive with the fee. To that extent, it represents a bundle of rights permanently carved out of the land. A nonperpetual easement, however, is more analogous to a leasehold. In a relevant decision ${ }^{49}$ dealing with such an easement, the taxpayer had conveyed a right of way across his land to a strip miner for a

46 Rev. Rul. 59-121, 1959-1 Cum. Bulz. 212; Rev. Rul. 57-445, 1957-2 Cum. Bull. 568; Rev. Rul. 55-295, 1955-1 CuM. Buld. 373; Rev. Rul. 54-575, 1954-2 CuM. Bull. 145.

47 See I.T. 2621, XI-1 Cus. Bulc. 67 (1932); note 45 supra.

48 There is no case directly on point. If, however, the owner of the easement has obtained "property" for capital gains purposes, income derived therefrom should be taxable to him. Compare Blair v. Commissioner, 300 U.S. 5 (1937), with Helvering v. Horst, 311 U.S. 112 (1940).

49 Ebb B. Nay, 19 T.C. 114 (1952); cf. Commissioner v. Southwest Exploration Co., 350 U.S. 308 (1956). 
three-year period. The taxpayer, contending that the consideration received should be treated as capital gain, argued that he had sold an interest in real property. The Commissioner countered that the transaction was in essence a lease with a three-year term. The court held for the Commissioner, stating that "a grant of a limited easement, such as here involved, does not constitute a sale of real property. The term 'sale' generally imports the transfer of all right, title, and interest in the property transferred." 50

Whether the decision would have been different had the term of the easement been longer is unclear. The case does suggest, however, that in the $A B C$ situation the duration of the leasehold could be a crucial consideration, but the line which might be drawn should not be made to depend on whether the interest created is perpetual or limited. The economic effect on the servient property owner of a longterm conveyance could be the same as that of a perpetual interest. A useful analogy can be found in the regulations to section 1031 which recognize a leasehold of 30 or more years duration as property of like kind to a fee. ${ }^{51}$

Without resolving at this juncture the question of the duration of the leasehold, the significant proposition for purposes of the present discussion is that a solely possessory contractual right will be recognized as an independently existing interest in property.

\section{Conclusions}

Under state law, a leasehold is a contractual right, treated as personalty rather than as an estate in real property. ${ }^{52}$ The conveyance of the fee by $A$ to $B$ would result in an immediate transfer of title subject to the possessory rights of the holder of the leasehold. Therefore, by a narrow and formalistic approach, since B is the owner of the land, rent paid $C$ for the use of the land is taxable to $B$ even though $B$ has assigned the leasehold or permitted it to be carved out of the conveyance to him.

This sort of reasoning does not lead to sound results. The alternative conceptual approach, that $B$ at no time had the right to require the payment of rent to him and for that reason cannot be taxed on it, is also unsatisfactory. These counter contentions simply beg the question. The determination of the tax treatment must be made on the basis of a number of considerations which to some degree conflict with each other. These are the practical economic effects of the trans-

5019 T.C. at 119.

51 Treas. Reg. \$1.1031(a)-1(c) (1956).

52 See 1 American Law of Property $\$ 3.12$ (Casner ed. 1952). 
action on $A, B$, and $C$, the goal of uniform tax administration, and the desirability of affording reasonable predictability as to the tax consequences of business dealings. Although form alone should not govern, effect should be given to a form which is supported by substance even though it produces a result similar to that brought about by some other device having different tax consequences.

When the tenant has a high credit rating, the economic effect of the $\mathrm{ABC}$ technique is to provide $\mathrm{B}$ with financing in a form other than a loan. He obtains all of the economic benefits of a mortgage, without endangering any of his assets or his interest in the property. Although $\mathrm{C}$ is deprived of this security, he presumably is adequately protected by the tenant's credit position and will receive a profit equal to the normal rate of interest. ${ }^{53}$ Nevertheless, by every substantive legal standard, C's interest is a leasehold. Recognizing C's interest as a leasehold, it would follow from the precedents involving oil payments, ground rents, life estates, and easements that the purchaser of a fee subject to a leasehold in another party should not be taxed on the rent received by the holder of the leasehold. However, if C's leasehold is of relatively short duration, perhaps a different conclusion should follow for reasons discussed below.

\section{B. Anticipatory Assignment of Income}

The alternative challenge to the desired tax result of the $A B C$ transaction is that the sale of the leasehold to $C$ constitutes an anticipatory assignment of income. Although the case law dealing with

53 These results are best illustrated by considering the following example. The sales price is $\$ 100,000$ of which $B$ supplies $\$ 20,000$ and $C \$ 80,000$. The financing is for a period of twenty years at $5 \%$ involving payments of $\$ 528$ per month which is also the amount of the monthly net rental. The useful life of the property is forty years; the value of the land is $\$ 20,000$.

Taxfayer Taxable years

A

B

First 5 years

First 10 years

First 20 years

After 20 years

C
First 5 years

First 10 years

All 20 years
Taxable income (straight line depreciation) Mortgage

Leasehold

Proceeds derived from sale are taxable as either capital gain or ordinary income depending on the nature of the property in A's hands.

$\begin{array}{ll}\$ 3,238.40 & \text { None } \\ \$ 10,228.80 & \text { None } \\ \$ 40,000 & \text { None } \\ \text { Equal to net } & \text { Equal to net } \\ \text { rental receipts } & \text { rental receipts } \\ \text { less deprecia- } & \text { without any de- } \\ \text { tion of } \$ 2000 & \text { duction for de- } \\ \text { per annum. } & \$ 11,680 \\ \$ 18,441.60 & \$ 23,360 \\ \$ 33,131.20 & \$ 46,720\end{array}$

$\$ 18,441.60$

$\$ 11,680$

$\$ 33,131.20$

$\$ 46,720$

$\$ 23,360$ 
assignments of income is confused, ${ }^{54}$ it is clear that a life estate is a capital asset and that its sale or assignment results in capital gain to the grantor or assignor. ${ }^{55}$ The sale of a long term leasehold interest is also accorded capital gains treatment. ${ }^{56}$ The Code even permits transfers of property to a trust having a duration of only ten years without considering the income earned during that period as taxable to the grantor. ${ }^{57}$

On the other hand the oft quoted doctrine that the "fruit" is taxed to the owner of the "tree" is applied with relative ease to most short term transactions. In such instances, anticipatory assignments of income will not shield the assignor from taxation on the income thereafter received by the assignee.

The most troublesome cases in this area are Commissioner $v$. P. G. Lake, Inc. ${ }^{58}$ and Hort v. Commissioner. ${ }^{59}$ The Lake case is bothersome more because of what it did not say than for what it held. It involved the assignment of short term oil payments. In essence, the assignors retained their basic oil interest and merely conveyed the right to receive a given number of barrels of oil or dollars from a stated percentage of production. Because all of the payments involved were of relatively short duration, the Supreme Court's conclusion that there was an assignment of future income taxable to the assignors as ordinary income seems patently correct. $^{60}$ The opinion, however, made it difficult to predict the fate of assignments of longer duration. The Court only stated:

We do not see here any conversion of a capital investment. The lump sum consideration seems essentially a substitute for what would otherwise be received at a future time as ordinary income. . . . The substance of what was received was the present value of income which the recipient would otherwise obtain in the future. In short, consideration was paid for the right to receive future income, not for an increase in the value of the income-producing property. ${ }^{81}$

Conceptually, the value of all income-producing property reflects the anticipated future income to be derived from it. Therefore, even

54 See generally Lyon \& Eustice, Assignment of Income: Fruit and Tree as Irrigated by the P. G. Lake Case, 17 TAx L. Rev. 295 (1962).

55 See Allen v. First Nat'l Bank \& Trust Co., 157 F.2d 592 (5th Cir. 1946); cases cited notes 41-42 stipra.

56 See Rev. Rul. 60-4, 1960-1 Cum. Buld. 303.

57 INT. Rev. CoDE of 1954, \$\$ 671, 673.

58356 U.S. 260 (1958).

59313 U.S. 28 (1941).

${ }^{60}$ See Note, Federal Income Taxation of Oil Payment Transactions, 104 U. PA.

L. REv. 1088 (1956).

61356 U.S. at 265-66. 
the seller of a fee sells future income, though his conveyance is said to involve the "tree" that produces the income and thus is characterized as a sale of property. The entire fee need not be sold to transfer the "tree"; at some point short of outright ownership of the fee itself, the transfer of a property interest, including a leasehold, will also shift the incidence of taxation. The issue is where to locate that point. Considering the congressional standard of ten years in the case of short-term trusts, the thirty-year period specified in the regulations dealing with like-kind exchanges, and the mathematically computed standard of twenty-one years representing the period of time over which a three and one-half percent annual return will have to be earned for the present value of the income to amount to more than fifty percent of the total sum, a leasehold should perhaps be considered of sufficiently long duration when it involves twenty years or more.

The implications of the Hort decision and related cases are even more pertinent to the tax questions arising from the "sale" of a leasehold. In Hort, the taxpayer owned property subject to a lease having a nine-year term remaining. He and the tenant entered into an agreement to cancel the lease in consideration of a payment of $\$ 140,000$. The Court stated, "The cancellation of the lease involved nothing more than relinquishment of the right to future rental payments in return for a present substitute payment and possession of the leased premises." 82 On that basis the amount received by the landlord was held taxable to him as ordinary income. This holding seems beyond dispute, particularly since the taxpayer, regaining possession of the premises, had the right to seek a new tenant for the balance of the term, as well as for future periods. Cases closely allied with Hort have held that rent received in advance is taxable in the year of receipt. $^{63}$ Generally, the issue in these cases is not whether the payment is taxable as ordinary income, but when it is taxable. In other decisions, payments purporting to be in consideration for the sale or assignment of a lease have been held taxable as rent because the assignor-vendor and the assignee-vendee were said to be in substance landlord and tenant. In the oil business, for example, where a royalty arrangement is regarded as a lease, a lump sum payment, referred to as a bonus, made by the driller to the landowner, is held to be advance rental when the landowner will also be paid royalties when oil is produced. ${ }^{64}$ The

62313 U.S. at 32.

63 See cases collected in 2 Mertens, Federal Income Taxation $\$ 12.30$ (1961).

64 See Burnet v. Harmel, 287 U.S. 103 (1932). For cases involving real estate, see Lindley's Trust No. 1 v. Commissioner, 120 F.2d 998 (8th Cir. 1941); Crile v. Commissioner, 18 B.T.A. 588 (1929), aff'd, 55 F.2d 804 (6th Cir. 1932); Rev. Rul. 57-537, 1957-2 CuM. BuL. 52. 
result is sharply altered, however, if the "bonus" is the entire consideration. It is then treated as capital gain. ${ }^{65}$

From this discussion of anticipatory assignments of income a synthesis seems to emerge. If the interest assigned is short lived, the proceeds are future income; if a long-term interest is assigned, it is regarded as property and the consideration is taxed as capital gain. If a periodic payment is made for the use of property, any lump sum received in addition is taxable as ordinary income; but if the lump sum is the sole consideration, it is regarded as capital gain from the sale of property.

Whether the receipt of the entire rental in advance on the conveyance of a long-term leasehold would, despite the foregoing analysis, be taxable as ordinary income to the landlord in the year of sale is unsettled. If such a case were to arise, the argument would undoubtedly be made that there was no sale or exchange of property but merely a lease. This, however, begs the question whether the leasehold is property to the lessee. The principal difference between such a situation and the $A B C$ transaction is that insofar as $A$ is concerned, there is no continuing lessor-lessee relationship since he has conveyed his entire interest.

With respect to $B$, a formalistic argument that he received no consideration and made no assignment also begs the question. Nevertheless, under the synthesis suggested, if the leasehold in the $A B C$ situation is of long duration, its transfer should not be considered an anticipation of income by $B$. Such a conclusion would contort substance as well as form.

Whether $A$ or $B$ are in receipt of ordinary income upon the sale of a leasehold to $C$ is not clear cut. The lack of precedents and the difficulties of characterization becloud the issue. The likelihood of achieving the objective of the $A B C$ transaction in real estate acquisitions seems good, but failure could result in the bunching of the entire sale price as income in one year. ${ }^{66}$

\section{Modification of the Basic ABC Pattern}

\section{A. Lien on the Fee}

We have seen that a major obstacle to B's successful use of the $\mathrm{ABC}$ technique is persuading the Commissioner or a court to dis-

65 Helvering v. Elbe Oil Land Dev. Co., 303 U.S. 372 (1938); Metropolitan Bldg. Co. v. Commissioner, 282 F.2d 592 (9th Cir. 1960); Rev. Rul. 60-4, 1960-1 Cum. Bull. 303.

66 If it is held that the conveyance of a leasehold to $C$ was an anticipatory assignment of income by $B$, it is possible that $B$ will be taxed on it as $C$ receives the rent. Such a result, however-which is the same as treating C's interest as an indebtedness -only seems appropriate when the assignment was a gift. 
tinguish the leasehold from an indebtedness. If the form of the $A B C$ transaction were varied to provide $C$ with a greater degree of security, $B$ 's chances of resisting the contention that C's interest is a mortgage would be substantially diminished.

The most obvious security that could be given $\mathrm{C}$ would be a lien on the fee. This would be analogous, in the area of oil payments, to providing the holder of an oil payment with a lien on the working interest. The Supreme Court has held in such a situation that the holder of the oil payment is no longer entitled to a depletion deduction as he has severed his investment from the oil in place. ${ }^{67}$ Since the success of the ABC technique in Thomas $v$. Perkins depended on the fact that the holder of the oil payment had an interest unsevered from the oil in place, entitling him to the depletion deduction, the change in result caused by giving $C$ a lien on the fee might be persuasive in attacking B's tax position in an ABC real estate transaction.

\section{B. Personal Guaranty From $B$ to $C$}

If $\dot{B}$ guarantees to $C$ the payment of the rent called for in the lease between $C$ and the tenant, the same adverse consequences are likely to result. Just as providing $\mathrm{C}$ with a lien moves his interest closer to that of a mortgagee, the personal guaranty of $\mathrm{B}$ moves the transaction closer to a simple loan secured by an assignment of rent. In both cases, the substance of the "leasehold" no longer matches its form; instead it is essentially an indebtedness.

\section{Providing C With a Greater Equity Position}

In the standard $A B C$ transaction, $C$ 's risks are its ability to lease the premises and the credit position of the tenant. As was indicated, these risks might be so remote as to merit regarding the leasehold as a "gilt-edged security" and treating it as a mortgage. If $\mathrm{C}$ had a greater equity position in the transaction, however, the analogy between its interest and an indebtedness would be more remote, thus enhancing the chances of achieving the desired tax result. If, for example, the property were untenanted when the leasehold is acquired so that $C$ would have to assume a real risk of securing tenants, $C$ would not appear to be a mere creditor. The analogy to indebtedness would also fail if $C$ had an option to extend the term of the lease.

Realistically, however, this can be accomplished only if $B$ and $C$ are both entrepreneurs willing to divide the risks. Such a situation departs considerably from the basic $A B C$ approach which seeks only

67 Anderson v. Helvering, 310 U.S. 404 (1940). 
to secure for $B$ a current deduction for the cost of acquisition without sacrificing the benefits of ownership. Nevertheless, this modified ABC transaction might be useful to finance speculative ventures.

The form of many real estate syndications is essentially such a variation of the $A B C$ technique. Recently the promoter of a multimillion dollar syndication arranged to purchase a building for an agreed consideration and then induced a third party to participate by becoming the "owner" of the fee upon payment of $43 \%$ of the total consideration. The public, organized in a limited partnership, was allowed to participate in an amount equal to the remaining $57 \%$. The limited partnership was also to be the prime tenant, leasing the entire building. To the extent that the funds needed could not be raised through this offering, the promoters intended to borrow, securing the loan by a mortgage on the leasehold. The promoters were also members of a joint venture which was to sublease the entire building from the limited partnership. The spread between the rent payable by the limited partnership and that receivable by it from the joint venture was calculated to yield on a net basis a constant return of $9 \%$ of the amount invested over the initial thirty-year term of the lease. Discounting amortization of the initial investment, this meant that the participants in the partnership would earn approximately $7.9 \%$ yearly on their money during the basic term, at the end of which they would have recouped all of their initial investment. The potential profit to the limited partners over and above this return would be in the renewal periods. The rent payable to the purchaser of the fee would be reduced considerably after the initial thirty years as would the rent received from the joint venture-sublessee. The joint venture, because of its rent reduction, would also achieve its principal profit in the renewal period, since the net fixed rental expense assumed by the joint venture was less than the rentals received from tenants in prior periods.

Relating this transaction to the alphabet, the prior owner is $A$, the purchaser of the building is $\mathrm{B}$, and the limited partnership is C. That the pattern fits somewhat uncomfortably is attributable primarily to the fact that payments to $C$ could be extended by renewal of the lease. Nevertheless, the purpose of having the partnership in the transaction was obviously to supply the bulk of the financing needed to complete the purchase, and in that respect its role was that of $\mathrm{C}$, the financier.

The absence of a limited and fixed payment to $C$, normally associated with an indebtedness, probably forecloses argument that the rental payments by the joint venture to the partnership should be treated as mortgage payments for the benefit of the landowner. Therefore, the rents received by the partnership should be taxable to it, and 
only the net rental paid by the partnership should be considered income to the purchaser of the building.

But the alternative potential contention of the tax authorities, that $B$, the purchaser, was in receipt of advance rent equal to the consideration paid by the partnership to the seller for the leasehold, cannot be dismissed as readily. If the form of the transaction had been such that the partnership made the payment to the purchaser, and the latter paid it over to the seller, in view of the continuing rental payable by the partnership, its initial payment would be taxable to the purchaser as advance rent or a bonus. ${ }^{8 \dot{8}}$ The only counter argument under such circumstances would be that the purchaser had "sold" a leasehold which should be treated for tax purposes as "property" rather than future rent. In terms of what might be considered a sounder rationale of the income-property dichotomy, this contention should be sustained only if the initial term of the lease is for a period of thirty years or more, as is the case here. ${ }^{69}$ However, the cases holding that lump sum payments by a tenant to the landlord are taxable as ordinary income are too deeply ingrained in the tax law to expect a favorable reception to such a contention. ${ }^{\text {70 }}$

The actual transaction, however, did not take the form hypothesized. The partnership acquired its interest directly from the seller. The purchaser of the building, in fact, received nothing from the partnership; it simply purchased an undivided interest in the building subject to a previously established lease. While it might appear that reliance on the form of the transaction as controlling the tax result flaunts the doctrine of substance over form, in this instance the substance is reflected in the form, The "purchase" of a leasehold for a term of thirty years analytically involves a sufficient interest to be regarded as "property" existing apart from the fee regardless of who transferred the leasehold. ${ }^{71}$ It was only because of established legal precedents involving the treatment of payments by lessees to lessors that it was assumed in the earlier discussion that the lessor would be taxable with whatever amounts were paid to it directly by the lessee. But when that fact is lacking-the payment for the leasehold not being made to the lessor-it is inappropriate to treat such payment for tax purposes as advance rent or as a bonus payable for the benefit of the purchaser. The parties did not consider the payment as anything. other than it was in form; in substance the partnership acquired a

68 See cases cited note 64 supra. If the purchaser were taxable with the amount received from the partnership, its basis for depreciation would likewise be increased.

69 See note 51 supra and accompanying text, and text following note 61 supra.

70 See, e.g., cases cited note 64 supra.

71 See notes 50-51 supra and accompanying text, and text following note 61 supra. 
leasehold subject to a stated rental obligation, and, as a necessary corollary, the purchaser of the building also acquired the property subject to the reciprocal right. ${ }^{22}$

The fact that the technique involved does not fit squarely within the $A B C$ pattern attests to the art of the promoter. The transaction enabled the promoter to sublet the building for a period, including renewals, in excess of 100 years; take current rent deductions for what was essentially the cost of acquisition, thus writing off the financing cost as a tax deduction; and secure the needed funds by the sale of interests in the master lease to the public. If the operation of the building is successful, the promoter, through the joint venture, will have acquired a substantial equity interest in the operating lease for a relatively small investment. The tax advantage of a current deduction for what is essentially the cost of acquisition of the prime lease is also available to the limited partners. Finally, the purchaser of the building will have acquired the building for an investment amounting to approximately $43 \%$ of the total price without being accountable for the rent received by the prime and subtenants, thus achieving the same tax advantage as the promoter and the limited partners.

\section{Miscellaneous Observations}

In a leaseback, with a long term lease, the nonrecognition provisions of section 1031(a) may be applicable to A. The Regulations provide that no gain or loss is recognized in the event a taxpayer exchanges a leasehold with thirty years or more to run, for real estate; ${ }^{\text {t8 }}$ the converse transaction produces the same result. ${ }^{74}$ Of course, this nonrecognition would not alter the tax consequences to $B$ or $C$.

When the lease provides renewal options, a related problem concerns the amortization of C's basis in the leasehold, ${ }^{75}$ as well as A's basis in its lease, should the transaction involve a leaseback to which the nonrecognition provision applies. Section 178 permits amortization of the cost of acquiring a leasehold over the initial term of the lease alone, if $75 \%$ or more of the cost of acquisition is attributable to the initial period. ${ }^{76}$ The Regulations ${ }^{77}$ indicate that in appropriate cases the apportionment of the cost may be made on the basis of the

72 The ABC transaction described in note 22 supra is similar to the syndication described in the text in that a portion of the proceeds of production were shared by $\mathrm{B}$ and $\mathrm{C}$.

73 Treas. Reg. $\$ 1.1031$ (a)-1(c) (1956).

74 See Century Elec. Co. v. Commissioner, 192 F.2d 155 (8th Cir. 1951).

75 See note 17 silpra.

78 INT. REv. CODE of 1954, §178(c) provides for amortization over renewal periods if there is reasonable certainty that the lease will be extended even though $75 \%$ of the cost is attributable to the initial period.

77 Treas. Reg. \$1.178-1 (b) (5) (1960). 
ratio which the present value of an annuity for the period involved in the initial term bears to the present value of an annuity for the entire period, including all potential renewals. The example included in the Regulations considers an interest factor of $5 \%$ in arriving at present value. Presumably this rate will vary with conditions prevailing in the money market and the credit risk of the parties.

In the normal $A B C$ case it is unlikely that the leasehold acquired by $\mathrm{C}$ will provide for renewal options. If, however, the holder of the leasehold is granted renewal options, as in the syndication transaction, the amortization of the cost of the leasehold over the initial period is extremely important. It should be noted, for example, that the leasehold interest acquired by the public participants in that transaction called for an initial term of thirty years with four renewal options of twenty-one years each, extending the potential term of the leasehold to one hundred fourteen years. On the basis of the ratio of the present value of an annuity for thirty years to the present value of an annuity for one hundred fourteen years, both discounted at $5 \%$, the cost attributable to the initial term was $77 \%$, thereby permitting amortization of the entire cost over the initial thirty-year period, unless "the facts show with reasonable certainty that the lease will be renewed, extended, or continued." 78

\section{CoNCLUSION}

The $A B C$ transaction, as developed in the oil industry and applied to the real estate field, presents interesting tax possibilities. Although the tax consequences are not certain, the purchaser of the fee, following the format described, has a better than even chance of success in writing off the amount "financed" over the period of its payment by not having to include in his income the amounts paid to the financier. Even if the financier's interest should be characterized as an indebtedness, the risk of financial detriment is small. The tax objective would not be obtained, and there would be a remote possibility of more serious bunching of taxable income if the amount paid by $\mathrm{C}$ for its leasehold were to be considered ordinary income taxable to the seller or purchaser in the year of payment. If the consideration paid by the purchaser was adjusted on the assumption that he would not be taxed for any income until the termination of the leasehold, $B$ will have overpaid if the desired tax consequences are not achieved. In appropriate circumstances the tax result can be made more certain by providing the financing party with more of an equity position.

78 Int. Rev. Code of 1954, § 178(c). 
The basic problems discussed with respect to the characterization of the interests involved have been with us for a long time. As draftsmen carve up with increasing skill the various incidents of property ownership, the probable tax results become less clear. To the extent, however, that new devices prove workable and successful in saving or deferring taxation, the necessity for remedial legislation will increase. This will particularly be so if it should develop that one segment of the economy, the oil industry for example, whether because of local law or an anachronism in the development of tax law, benefits in a way unavailable to the rest of the economy. With this in mind, we look forward with great interest to the promised publication of the Commissioner's position on the tax treatment of the $A B C$ transaction as applied to the oil industry. 